\title{
Relationship of Life Satisfaction and Job Satisfaction among Pakistani Army Soldiers
}

\author{
Summaira Naz \\ Hazara University, \\ Psychology Department, \\ Mansehra, Pakistan \\ sumaira_naz_awan@yahoo.com
}

\begin{abstract}
The present study had two main objectives; first, to discover the relationships between job satisfaction and life satisfaction in Pakistani army soldiers, second, to find out the age, salary, marital status, and education differences on job satisfaction and life satisfaction in Pakistani army soldiers. In the present study two questionnaires; Job Satisfaction Scale JSS (Macdonald \& Maclntyre, 1997) and Satisfaction With Life Scale (Diener, et al., 1985); were administered to a sample $(\mathrm{N}=400)$ along with a demographic sheet. The results of the study revealed a significant positive correlation between job satisfaction and life satisfaction of Pakistani army soldiers. The findings of the study also showed a significant age, education, salary, and marital status differences in job satisfaction and life satisfaction. Age, marital status, and salary variables had positive correlation with job satisfaction and life satisfaction but education had a negative association with job satisfaction and life satisfaction.
\end{abstract}

Keywords: Relationship, Life Satisfaction, Job Satisfaction, Pakistani, Army Soldiers

\section{INTRODUCTION}

In the last decade a dramatic increase in research on the construct of subjective well-being has seen (Diener \& Larsen, 1993). This research begun to provide a very important complement to one of contemporary psychology's traditional goals: understanding mental illness in the form of depression, anxiety, and unpleasant emotions. Researches have identified two broad aspects of subjective well-being: affective component (usually further divided into unpleasant and pleasant affect (Diener, 1990); and a cognitive component (life satisfaction) which generally received less attention than subjective well-being component (Andrews \& Withey, 1976; Diener, Emmons, Larsen, \& Griffin, 1985).

Life satisfaction is defined as a judgmental process in which individuals assess the quality of their lives on the basis of their own unique set of criteria (Shin \& Johnson, 1978). Therefore, life satisfaction is a conscious cognitive judgment of one's life in which the criteria for judgment are made by the person (Pavot, \& Diener, 1993). Life 
satisfaction explains the difference which emerged after the comparison of individual's expectations with the real situation. Through research it was found that those individuals who are satisfied with their lives are also satisfied with their current jobs.

Job satisfaction is an important criterion for the success of an organization. It has a close association with job turnover and life satisfaction. Job satisfaction can also be defined as the extent that the working environment meets the needs and values of employees and the individual's response to that environment (Camp, 1994; Lambert, 2004; Tewksbury \& Higgins, 2006). Job satisfaction is a multi-dimensional concept as it includes several domains (e.g., satisfaction with pay, fringe benefits, the importance/challenge of the job, promotion opportunities, and job security). For the organization, job satisfaction of its workers means a work force that is fully motivated and committed to high quality performance (Baloch, 2008). Job satisfaction can predict how workers feel about their jobs and also predict work behaviors such as organizational citizenship, turnover, and absenteeism.

One common research finding is that job satisfaction is correlated with life satisfaction (Rain, Lane, \& Steiner, 1991). This correlation is reciprocal because people who are satisfied with life tend to be satisfied with their job and vice versa. However, some research has found that when other variables such as non-work satisfaction and core self-evaluations are taken into account then job satisfaction is not a significantly related to life satisfaction (Rode, 2004). Some researchers would even say that this is basically all that matters. Thus we find many philosophers, including Nozick (1974) and Sumner (1996), taking something as important as happiness to consist largely or wholly in being satisfied with one's life. Sumner (1996) further found by placing life satisfaction at the center of his account of well-being as authentic happiness: being happy, where one's happiness is solidly grounded both in reality and in the values that are truly one's own; deceived experience machine users and brainwashing victims thus don't count as flourishing. The life satisfaction component of this theory clearly gets the most weight, so that Sumner (1996) actually refers to it as a life satisfaction theory of happiness.

\section{LIFE SATISFACTION}

Life satisfaction implies contentment with the circumstances of life and with the satisfaction of one's wants and needs of one's life as a whole. It has been defined as a person's subjective and global evaluation of the positivity of her/his life as a whole or with specific life domains (Diener, Suh, Lucas, \& Smith, 1999). Recent years have seen an increase in overall research on subjective well-being (Diener \& Emmons, 1985). Life satisfaction Judgments are dependent upon a comparison of one's circumstances with the idealized appropriate standard. This judgment of how satisfied people are linked with their present state of affairs. It is not externally imposed as it based on a comparison with a standard which each individual sets for him or herself.

Chen and Crewe (2009) said that informed desire theory suggests that life satisfaction is contingent upon satisfying the goals that informed people would desire to pursue. Variables that have been closely linked to higher life satisfaction for persons with disabilities include age (Mehnert, Krauss, Nadler, \& Boyd, 1990), employment status (Viemero \& Krause, 1998), income (Boschen, 1996), marital stress (Mehnert et al., 1990), and age at the onset of the disability (Mehnert et al., 1990). Ahlstrom and Sjoden (1996) indicated that the prevalence rate of low quality of life in people with 
muscular dystrophy (MD) could be partially explained with the help of their tendency to utilize emotion-focused coping when facing stressful problems.

\section{Life Satisfaction, Subjective Well-Being and Life Domain Satisfaction}

According to Diener et al., (1999), subjective well-being has both cognitive component and affective components. The affective component study how frequently an individual report experiencing positive and negative affect. Researchers differentiate between life-domain satisfaction and life-as-a- whole (or global) life satisfaction. They said that life-domain satisfaction study individual's life satisfaction with specific areas (e.g., work, income, and marriage) but the judgments of global life satisfaction are much broader, which comprised on an individual's comprehensive judgment of her life (Sousa \& Lyubomirsky, 2001).

\section{Sources of Life Satisfaction}

Materialistic things never cause life satisfaction, it basically comes from what you do and the way you use what you have. Only you can truly answer the question what will make you satisfied with your life? According to Perera (2010) some of these needs which become the sources of life satisfaction are: Friends, Successful relationships, Family (provide a sense of identity and belonging), Feeling that you are needed and loved, Purpose in life (a difficult one but so important), having choices and options, having achievable goals, doing what you enjoy, having the possibility to express yourself creatively and emotionally, feeling that you have a value (this is your selfesteem), being understood and accepted for who you are.

\section{Determinants of Life Satisfaction: Personality vs. Environment}

One of the principal questions that researchers are tackling is what causes life satisfaction? Most of the research in this area can be counted under two categories, namely, evidence implicating personality (i.e., genetics, inborn traits) and evidence implicating environment (i.e., life circumstances and life events). A great deal of research work investigated that whether life satisfaction is a stable, enduring trait or whether it is a variable that is highly influenced by external events and life circumstances. For example, will the experience of harassment or discrimination, the birth of a child, a divorce, purchasing a house, obtaining an advanced degree, or the day-to-day hassles of balancing work and home life greatly influence a woman's satisfaction with her life? On the other side, a woman's stable characteristic pattern of responding to events determine her life satisfaction, such that she remains satisfied (or dissatisfied) despite changes in income, social relationships, employment, or other significant life events (Sousa \& Lyubomirsky, 2001).

In support of the latter view, research has shown that individuals tend to show similar levels of satisfaction across time and many life domains. For example, women who are content with their marriages are also likely to be content with their work, their children, their financial situation, and even the daily weather. However, this finding should not be overstated, as it is possible to be dissatisfied with one's partner but satisfied with one's job. In support of an alternative point of view, another study found that the proportion of positive to negative life events experienced by an individual during the previous year predicted his/her life satisfaction during the following year. It also suggests that life events, such as a new marriage may indeed significantly boost one's overall life satisfaction (Sousa \& Lyubomirsky, 2001). 
Eunkook Suh and his colleagues found that the occurrence of specific life events in students' lives was related to changes in their well-being but these effects did not endure. His study concluded that personality or environmental explanations in isolation may not be sufficient to explain the source of people's life satisfaction judgments. However, it might be impossible to entirely discriminate between these two sets of components because one's personality might influence one's life events. Certainly, Robert Plomin and his colleagues provide evidence that genes also have a small influence on the actual types of life events people experience. The combined results of these findings suggest that life satisfaction is stable over time and consistent across situations (as cited in Sousa \& Lyubomirsky, 2001).

\section{Demographic Variables as Predictors of Life Satisfaction}

Studies in the U.S. on life satisfaction found that life satisfaction has positive relationships with employment status, marital status, age at the onset of disability, social support, and educational attainment (Boschen, 1996; Decker \& Schulz, 1985; Krause \& Dawis, 1992; Mehnert, Krauss, Nadler, \& Boyd, 1990). The vast majority of research on life satisfaction investigates the extent to which various demographic variables predict life satisfaction.

Culture: Research shows that members of individualist cultures report higher level of satisfaction as compared to members of collectivist cultures. Eunkook Suh and colleagues found that members of collectivist cultures appear to rely on cultural norms to determine their life satisfaction judgments, whereas members of individualist cultures appear to rely on emotional experiences as their guide to life satisfaction judgments. Similarly cultures with greater acceptance of differences (e.g., gender, sexual orientation, age, ethnicity) and those that demand equal treatment of opportunity for their citizens, appear to foster greater overall satisfaction (as cited in Sousa \& Lyubomirsky, 2001).

Gender: An apparently ironic finding in the literature is that women show higher rates of depression as well as higher levels of well-being than men; but at the same time majority of studies find no gender differences in life satisfaction. These conflicting findings can be resolved by considering the range of affect that men and women typically experience. Women report experiencing affect -- both positive and negative with greater intensity and frequency than do men, so women tend to experience greater joy and deeper sadness and experience these emotions more often than do men (Sousa \& Lyubomirsky, 2001). Despite similar levels of life satisfaction across gender, women and men appear to derive life satisfaction from different sources. For example, Ed Diener and Frank Fujita found that though social resources (i.e., friends, family, and access to social services) are major predictors of life satisfaction for both genders, but these resources are more predictive for women' life satisfaction (as cited in Sousa \& Lyubomirsky, 2001).

Age: Several studies have provided evidence that life satisfaction does not decline with age which is contrary with traditional views. For example, Diener and Suh found that reported life satisfaction generally remained stable throughout the life span but has a slight increasing trend of life satisfaction appear from 20-80 years of age. The principal explanation for this surprising lack of difference in life satisfaction levels across the life span is that people have an extraordinary capacity to adapt to significant life changes (as cited in Sousa \& Lyubomirsky, 2001). 
Income: A strong finding indicates that the greater the economic disparities between income levels and classes in a nation, the greater the dissatisfaction expressed overall and the greater the disparity between satisfaction levels of the wealthy and the poor. So, women who live in poorer or less egalitarian nations and tend to be less satisfied with their lives overall than women who live in wealthier nations (Headey \& Wearing, 1989). Despite significant correlations between life satisfaction and wealth, one longitudinal research has shown that increases in people's incomes do not necessarily correlate with increases in life satisfaction (Pinquart \& Sorensen, 2000).

Education: Researchers have found a low correlation between education and life satisfaction, which appears to disappear when income and occupation are statistically controlled. So the relationship between education and life satisfaction is possibly due to the fact that a high level of education is associated with high income. Education also provides access to greater occupational and income opportunities which influence life satisfaction (Argyle, 1999). Recent studies found that in wealthy nations highly educated individuals seem to be slightly dissatisfied with their lives (Veenhoven, 1996).

\section{Life Satisfaction and Five Factor Model}

Life Satisfaction is a theoretical construct that cannot be observed directly. Neugarten, Havighurst, and Tobin's theoretical framework provided an operational definition of the latent variable of life satisfaction which consists of following five following variables (as cited in Barrett \& Murk 2006):

Zest vs. Apathy: It is generally relates to enthusiasm of response to life in and not related to any specific activity (social or intellectual engagements). Both physical energy and intellectual energy are involved pursuits contributed to a high score.

Resolution and Fortitude: It measures the respondent's active acceptance of personal responsibility for their lives rather than passively accepting or condoning what has happened to them.

Congruence between Desired and Achieved Goals: It measures the relative difference between desired and achieved goals cause one to be satisfied or dissatisfied with life in this rating.

Self-concept: It comprises on one's current physical, emotional, and intellectual dimensions. Individuals who do not feel old but concerned with their appearance and mostly judge themselves as wise and competent, they rate themselves higher on this factor.

Mood Tone: It deals with happiness, optimism, and other positive affective responses. Individuals get fewer score due to sadness, depression, loneliness, pessimism, and irritability.

\section{JOB SATISFACTION}

Job satisfaction is described as the degree of congruence between characteristics of a job and the employee's perceived qualities. Weiss (2002) suggested job satisfaction is an attitude but points out that researcher should clearly distinguish the objects of cognitive evaluation that influence affects (emotion), beliefs and behaviors. This definition shows that we form our attitudes towards our jobs by considering our feelings, our beliefs, and our behavior. As far back as the 1960s, scholars pointed to confusion about the concept. For example, Vroom (1964) stated that the job satisfaction 
and job attitude were used interchangeably since both refer to the affective orientation of the individuals to the work role he is occupying. Since then, the researcher has tried to define the job satisfaction more specifically, through a single, widely held definition has proved elusive. Ewen, Smith, Hulin, and Locke, (1966) found that if the presence of a variable in the work situation leads to satisfaction, then its absence leads to job dissatisfaction.

One of the most significant developments regarding the concept of job satisfaction was the Herzberg's two-factor theory, which was introduced by some of the earliest research in job satisfaction and gained favor as time passed (Herzberg, 1966). Hertzberg contended that job satisfaction and job dissatisfaction were two separate concepts. The factors which affect job satisfaction is named as intrinsic factors or motivation (e.g., work itself, recognitions, responsibilities, achievements, and advancements). Extrinsic factors influence the job dissatisfaction (e.g., pay, administration, company policy, relationships among colleagues, and working environment). Herzberg proposed that intrinsic factors influence job satisfaction and extrinsic factors influence job dissatisfaction (as cited in Hussain, 2006).

The two-factor theory has been widely used in research. Still, it has been challenged. The most important criticism of this theory is that it fails to explain the different levels of job satisfaction among people with the same job characteristics (Kalleberg, 1977). Critics of this theory contend that job satisfaction is actually a function of the nature of a job and the characteristics of the job holding individual (Kalleberg, 1977; Martin \& Hanson, 1985). Martin and Hanson (1985) argued that job satisfaction should be understood as the fit between a worker's need and the work requirements on one hand and actual job characteristics on the other hand. Gruenberg (1980), and Lahiri and Srivasta (1967) found that the perceived importance of extrinsic rewards had a different affect among different occupational groups. He reported that unskilled, semiskilled and clerical workers in his research considered pay, job conditions and the social environment of the job more important than skilled workers or professionals and technical workers.

Some Previous researches found that monetary compensation is one of the most vital variables of job satisfaction (Kalleberg, 1977; Voydanoff, 1980). Similarly Taylor and Vest (1992) found that pay level affects job satisfaction. Job characteristics are another category of variables that have been found to consistently have an impact on job satisfaction level (Hackman \& Lawler, 1971). On the other hand, work environment characteristics are another category of variables that researcher found to have an effect on job satisfaction. Employee's job satisfaction is linked to supervisor characteristics (Harrick, Vanek, \& Michlitsch, 1986). Emmert and Taher (1992) said that for public professionals' job related feedback and the social environment are important determinants of their job satisfaction. Another set of variables that have attracted the attention of the researchers as possible predictors of job satisfaction are the employee's personal characteristics (e.g., educational level, age, and gender) which some relationships to the employee's level of job satisfaction.

\section{Theories of Job Satisfaction}

Various theories are constructed to explain what makes people satisfied with their jobs (Manisera, Dusseldrop, \& Kooij, 2005; Staples \& Higgins, 1998). The major theoretical conceptions of job satisfaction are: 
Maslow's Need Hierarchy Theory: Organizational psychologists often cited Maslow's need hierarchy theory as applicable to job satisfaction. This theory theorizes five kinds of human needs which arranged from most to least fundamental, they are: psychological needs, safety needs, social needs, esteem or ego needs, and self actualization need (Haleem, 2001). Maslow stated that only when the more fundamental needs are well met than the higher needs become apart. Job satisfaction should be determined by how well the job meets the needs that are central for an individual (Hussain, 2006).

Herzberg's Two Factor Theory: Herzberg (1966) proposed a theory about job factors that motivate employees (Gawel, 1997). Herzberg suggests two kinds of needs: physical needs and psychological needs, which operate on two different principles: Physical needs operate to avoid pain or discomfort (hygiene factors), while psychological needs strive for growth and creativity and operate on a pleasure principle (motivational factors).

Expectancy Theory: This theory holds that satisfaction is the result of what workers expect to get for their efforts as compared to what they actually get. Factors which determine the level of effort based on the utility of the money, motivation, and even the fairness of the pay administration system (Weiner, 1980). This theory usually regards overall job satisfaction as a function of satisfaction with various elements of the job (Greunberg, 1980).

Social Information Processing Theory: This theory approach to job satisfaction holds that satisfaction and dissatisfaction result from comparing oneself with other workers. This approach emphasizes the importance of social environment in shaping individual behavior (Haleem, 2001).

Opponent Process Theory: Landy proposed this theory of job satisfaction by using central nervous system functions. He said that it could be explained by excitatory and inhibitory actions of the brain. In the central nervous system, there are opposing processes that move the organism towards equilibrium. For job satisfaction worker needs additional excitatory phenomenon (as cited in Lounsbury, Moffitt, Gibson, Drost, \& Stevenson, 2007).

Genetic Theory: This theory considers dispositional factors as the major determinants of job satisfaction. Work in this area is based on the observation that some people are satisfied or dissatisfied with their job regardless of the working situation (Levin \& Stokes, 1989).

Locke's Value Theory: This theory claims that job satisfaction is related to the extent to which job outcomes match with the desires of the individual. The closer the match, the more people perceive they are receiving outcomes they value and the higher the job satisfaction. The key of this approach is the incongruity between aspects of the job one has and what one wants. Greater discrepancies create dissatisfaction and vice versa (Haleem, 2001).

Equity Theory: Adams's equity theory holds a social element in which individuals compare their input and outcomes against the outcomes of some other relevant person. When these ratios are equal, the workers feel that a fair and equitable exchange occurs which contributes to job satisfaction and vice versa (as cited in ALHussami, 2008). 
Dispositional Theory: This theory suggests that people have innate dispositions which cause them to have tendencies toward a certain level of satisfaction, regardless of their job. This approach became a prominent explanation of job satisfaction in light of evidence that job satisfaction tends to be stable over time and across careers and jobs (Wu \& Norman, 2006).

\section{Life Satisfaction and Job Satisfaction}

An emerging area of study is the relationship between job and life satisfaction. Researchers found three possible forms of the relationship between job satisfaction and life satisfaction; (1) spillover (job experiences spill over into nonworking life and vice versa); (2) segmentation (job and life experiences are separated and have little to do with one another); and (3) compensation (individual seeks to compensate for a dissatisfying job by seeking fulfillment and happiness in his or her nonworking life and vice versa). Review of research literature indicated that job and life satisfaction are correlated (Tait, Padgett, \& Baldwin, 1989). The researchers suggest that this relationship between job and life satisfaction is reciprocal in nature (Judge \& Watanabe, 1994).

Organizations only have so much control over a person's job satisfaction; because for many people their job satisfaction is a result, in part, of spillover of their life satisfaction. Review of theories and research on the relationship between job satisfaction and life satisfaction revealed the prediction that causal effects flow in only one direction: that is, job satisfaction causes life satisfaction but life satisfaction does not cause job satisfaction. Job satisfaction does not predict life satisfaction when the effects of other variables are controlled; similarly life does not satisfy predict job satisfaction (Near, 1983).

The job-satisfaction/life-satisfaction relationship provides an empirical index for examining the general issues of work non-work relations. Measures of work satisfaction, overall life, and specific facets of non-work life can be thought of as outcroppings of activities and sentiments in different realms of life. The strength of this empirical relationship between these outcroppings can provide an index of the strength with which work and non-work elements of life are related (Rice, Near, \& Hunt, 1980). In reviewing literature on these issues, it is helpful to discriminate between two different forms of life satisfaction measures. Many studies use measures of global life satisfaction; which require respondents to integrate their satisfaction with specific facets of life into a global judgment of overall life satisfaction (Near, Rice, \& Hunt, 1978). In the second procedure asks respondents to indicate their satisfaction with specific nonwork facets of life such as marriage, family, leisure, or community.

\section{Rationale of the Study}

Job satisfaction can be an important indicator of how workers perceive their jobs and a predictor of work behaviors such as organizational citizenship, absenteeism, and turnover. On the other side, an individual global assessment of one's life in positive terms is the definition of life satisfaction (Diener, Suh, Lucas, \& Smith, 1999). Life satisfaction can be assessed specific to a particular domain of life or globally. A wealth of material is available on the relationship between job satisfaction and life satisfaction (Andrews \& Withey, 1974a, 1976; Campbell, Converse, \& Rodgers, 1976; Hulin, 1969; London, Crandall, \& Seals, 1977; Rice, Near, \& Hunt, 1979). The present study investigates the relationship between life satisfaction and job satisfaction among 
Pakistani army soldiers to examine whether there is a significant relationship between soldier's job satisfaction and their life satisfaction? The Pakistani military is responsible for fighting and winning the nations' wars. Nowadays, the Pakistan army fights against terrorist/Alqaida mujahideen in many cities of Pakistan (e.g., Peshawar, Islamabad, Sawat, Quetta, DeraIsmael Khan), who are also Pakistani. So, in Pakistan it is a hot debate on media as well in the general community that who is right whether mujahideen or Pakistani Army? One of the seemingly major contributing factors behind this war is differences in religious perceptions of Pakistani army and terrorist/Alqaida mujahideen. So, in these circumstances it is very important to know that whether army soldiers are satisfied with their job and lives?

\section{METHOD}

\section{Objectives}

The objectives of the present study are as follows:

1. To explore the relationship between the level of job satisfaction and life satisfaction among Pakistani army soldiers.

2. To find out the influence of demographic differences (age, marital status, salary, and education) on job satisfaction and life satisfaction of Pakistani army soldiers.

\section{Hypotheses}

The hypotheses of the current study are enlisted below:

1. Soldiers' level of job satisfaction will be positively related to their level of life satisfaction.

2. The older Pakistani army soldiers will have a higher level of life satisfaction and job satisfaction than younger soldiers.

3. Low educated Pakistani army soldier will have higher levels of life satisfaction and job satisfaction than highly educated soldiers.

4. Married Pakistani army soldiers will have a higher level of life satisfaction and job satisfaction than unmarried soldiers.

5. Highly paid soldiers will be more satisfied with their lives and job than low paid soldiers.

\section{Operational Definitions of Variables}

The present study based on the investigation of relationships between two variables named; life satisfaction and job satisfaction. The operational definitions of these variables are given below:

Life satisfaction: Life satisfaction is defined as one's positive evaluation of his whole life according to the criteria determined by the individual himself (Diener et al., 1985).

Job Satisfaction: Locke (1976) defines the job satisfaction as job satisfaction is a self reported positive emotional state resulting from the appraisal of one's job or from job experience.

\section{Sample}

In the present study convenient sampling technique was used for sample selection from the Pakistani army soldier's population of Islamabad, Peshawar, Abbottabad, and 
Lahore. The sample size was $N=400$ with an age range of 20-50 years. The present sample was divided into two categories on the basis of age i.e., younger $=20-35$ years $(n=213)$, older $=35-50$ years $(n=187)$. Similarly this sample was also divided into two categories on the basis of marital status, married $(n=212)$, unmarried $(n=188)$. This sample was also further divided into two categories on the behalf of employees' educational level; Metric $(n=176)$, above metric $(n=224)$. The sample was further divided into two categories; high paid $(n=170)$, low paid $(n=230)$.

\section{Instrument}

In order to achieve the aforementioned objectives of the study two scales were used, The Satisfaction with Life Scale (SWLS) and Rosenberg's Self Esteem Scale (SES). The descriptions of the scales are given below:

The Satisfaction with Life Scale (SWLS): The Satisfaction with Life Scale (Diener, et al., 1985) is a five item scale with scoring on 7-point Likert scale, which is designed for an overall judgment of life of respondents in order to measure the concept of life satisfaction (Diener et al., 1985). Scores range from 5 to 35 (extremely dissatisfied $=5-9$, dissatisfied $=10-14$, slightly dissatisfied $=15-19$, neutral $=20$, slightly satisfied $=21-25$, satisfied $=26-30$, and extremely satisfied $=35-31$ ).

Job Satisfaction scale (JSS): Job Satisfaction scale (Macdonald \& Maclntyre, 1997) comprised upon 10 items with scoring on five-point Likert scale. The interpretation of this scale is done according to the ranges of scores; 42-50- very high, 39-41- high, 32-38- average, 27-31-low, 10-26- very low. This scale is most accurate for employees between the ages of 25 and 60 .

\section{Procedure}

For the purpose of the present research, the sample of Pakistani army soldiers was selected. The questionnaire of the Satisfaction with Life Scale (SWLS) and Job Satisfaction scale (JSS) along with The Informed Consent Form and Demographic Sheet, were distributed among the sample. So, in order to address the objectives of the study and to test the hypotheses of the study, according to the nature of the data appropriate statistical analysis was used through the SPSS package.

\section{FINDINGS}

In this study, the data of 400 Army soldiers have been analyzed. In order to address the aforementioned objectives and to test the proposed hypotheses, three statistical methods, alpha reliability coefficients, t-test, and Pearson Product Moment correlation coefficients have been used. The alpha coefficient for Satisfaction with Life Scale (SWLS) and Job satisfaction scale (JSS) are .833, .789, respectively, which indicates that these scales are internally consistent and will produce reliable results (see Table 1).

Table 1: Alpha Reliability Coefficients for (JSS), Satisfaction with Life Scale (SWLS,

\begin{tabular}{llcc}
\multicolumn{4}{c}{$N=400)$} \\
\hline S. No & Scale & No. of Items & Alpha Coefficients \\
\hline I & SWLS & 5 & .833 \\
II & JSS & 10 & .789 \\
\hline
\end{tabular}

Job satisfaction scale (JSS) and Satisfaction with Life Scale (SWLS) have good construct validity as all its items show significant positive association with the total 
scores questionnaires (see Table $2 \&$ 3). Table 4 shows significant positive relationships, $r(398)=0.825, p<.01$, between Job Satisfaction and life satisfaction of Pakistani army soldiers. It indicates that the soldiers' high level of life satisfaction leads towards their high level of life job satisfaction and vice versa.

Table 2: Item Total Correlation of Job Satisfaction Scale (JSS) (N=400)

\begin{tabular}{lccc}
\hline Item no. & $r$ & Item no. & $r$ \\
\hline JSS 1 & $.836^{* *}$ & JSS 6 & $.821^{* *}$ \\
JSS 2 & $.816^{* *}$ & JSS 7 & $.613^{* *}$ \\
JSS 3 & $.656^{* *}$ & JSS 8 & $.928^{* *}$ \\
JSS 4 & $.451^{* *}$ & JSS 9 & $.747^{* *}$ \\
JSS 5 & $811^{* *}$ & JSS 10 & $.616^{* *}$ \\
\hline
\end{tabular}

$* * p<.01$

Table 3: Item Total Correlation of Satisfaction with Life Scale (SWLS, N=400)

\begin{tabular}{lccc}
\hline Item No. & $r$ & Item no. & $r$ \\
\hline OCQ 1 & $.824^{* *}$ & OCQ 4 & $.840^{* *}$ \\
OCQ 2 & $.760^{* *}$ & OCQ 5 & $.752^{* *}$ \\
OCQ 3 & $.652^{* *}$ & & \\
\hline
\end{tabular}

$* * p<.01$

Table 4: Correlation coefficient between JSS and SWLS $(N=400)$

\begin{tabular}{lc}
\hline Scale & JSS \\
\hline SWLS & $.825^{* *}$ \\
\hline$d f=398, * * p<.01$ &
\end{tabular}

The findings describe significant age differences on JSS, as older soldiers had higher scores $(\mathrm{M}=46.08, \mathrm{SD}=7.95)$ than younger soldiers $(\mathrm{M}=40.70, \mathrm{SD}=2.381)$, $\mathrm{t}(398)=4.03, \mathrm{p}=.001, d=0.92$ (see Table 5).

Table 5: Independent T-Test analysis of Old and Young Pakistani Army Soldiers on JSS $(\mathrm{N}=400)$.

\begin{tabular}{llllllc}
\hline & $\mathrm{N}$ & $\mathrm{M}$ & $\mathrm{SD}$ & $\mathrm{t}$ & $\mathrm{p}$ & Cohen's d \\
\hline Old Soldiers & 187 & 46.08 & 7.950 & \multirow{2}{*}{4.031} & \multirow{2}{*}{.001} & \multirow{2}{*}{0.92} \\
Young Soldiers & 213 & 40.70 & 2.381 & & \\
\hline
\end{tabular}

$d f=398$

Similarly, the results of Table 6 describe significant age differences on SWLS, as older soldiers had higher scores $(\mathrm{M}=56.86, \mathrm{SD}=11.22)$ than younger soldiers $(\mathrm{M}=$ $49.20, \mathrm{SD}=7.02), \mathrm{t}(398)=3.99, \mathrm{p}=.001, d=0.82$. This difference indicates that the level of job satisfaction and life satisfaction increases among soldiers with their ages. Significant education differences occur on JSS because low educated soldiers had higher scores $(\mathrm{M}=44.94, \mathrm{SD}=7.92)$ than high educated soldiers $(\mathrm{M}=39.01, \mathrm{SD}=$ 4.38), $\mathrm{t}(398)=3.00, \mathrm{p}=.001, d=0.93$ (see Table 7).

Table 6: Independent T-Test Analysis of Old and Young Pakistani Army Soldiers on SWLS $(\mathrm{N}=400)$.

\begin{tabular}{llllllc}
\hline & $\mathrm{N}$ & $\mathrm{M}$ & $\mathrm{SD}$ & $\mathrm{t}$ & $\mathrm{p}$ & Cohen's d \\
\hline Old Soldiers & 187 & 56.86 & 11.22 & \multirow{2}{*}{3.987} & .002 & 0.82 \\
Young Soldiers & 213 & 49.20 & 7.021 & & & \\
\hline
\end{tabular}

$d f=398$ 
Table 7: Independent T-Test Analysis of High and Low Educated Pakistani Army Soldiers on JSS $(\mathrm{N}=400)$.

\begin{tabular}{llllllc}
\hline & $\mathrm{N}$ & $\mathrm{M}$ & $\mathrm{SD}$ & $\mathrm{t}$ & $\mathrm{p}$ & Cohen's d \\
\hline Low educated & 176 & 44.94 & 7.924 & \multirow{2}{*}{3.001} & .001 & 0.93 \\
High educated & 224 & 39.01 & 4.383 & & & \\
\hline$d f=398$ & & & & &
\end{tabular}

On the other side the findings of Table 8 shows significant differences of educational level on SWLS because low educated soldiers had higher scores $(\mathrm{M}=$ $58.36, \mathrm{SD}=79.65)$ than high educated soldiers $(\mathrm{M}=51.34, \mathrm{SD}=7.83), \mathrm{t}(398)=4.02, \mathrm{p}$ $=.001, d=0.80$. So, it shows that lower the academic qualification of soldiers the higher will be their level of job satisfaction and life satisfaction.

Table 8: Independent T-Test Analysis of High and Low Educated Employees on SWLS

\begin{tabular}{llllllc}
\hline & $\mathrm{N}$ & $\mathrm{M}$ & $\mathrm{SD}$ & $\mathrm{t}$ & $\mathrm{p}$ & Cohen's d \\
\hline Low educated & 176 & 58.36 & 9.651 & 4.02 & .001 & 0.80 \\
High educated & 224 & 51.34 & 7.830 & & & \\
\hline
\end{tabular}

$d f=398$

Significant marital status differences exist on JSS, as married soldiers had higher scores $(\mathrm{M}=43.21, \mathrm{SD}=3.63)$ than unmarried soldiers $(\mathrm{M}=38.42, \mathrm{SD}=7.68), \mathrm{t}(398)$ $=3.03, \mathrm{p}=.009, d=0.80$ (see Table 9). Significant marital status differences also emerged on SWLS, as it found that married soldiers had higher scores $(\mathrm{M}=57.28, \mathrm{SD}=$ 9.84) than unmarried soldiers $(\mathrm{M}=49.98, \mathrm{SD}=10.10), \mathrm{t}(398)=2.38, \mathrm{p}=.016, d=0.73$ (see Table 10). It reveals that married soldiers have high level of job satisfaction and life satisfaction than unmarried soldiers.

Table 9: Independent T-Test of Married and Unmarried Employees on JSS (N=400)

\begin{tabular}{llllllc}
\hline & $\mathrm{N}$ & $\mathrm{M}$ & $\mathrm{SD}$ & $\mathrm{t}$ & $\mathrm{p}$ & Cohen's d \\
\hline Married & 212 & 43.21 & 3.63 & \multirow{2}{*}{3.031} & \multirow{2}{*}{.009} & \multirow{2}{*}{0.80} \\
Unmarried & 188 & 38.42 & 7.68 & & & \\
\hline
\end{tabular}

$d f=398$

Table 10: Independent T-Test Analysis of Married and Unmarried Employees on SWLS $(\mathrm{N}=400)$

\begin{tabular}{llllllc}
\hline & $\mathrm{N}$ & $\mathrm{M}$ & $\mathrm{SD}$ & $\mathrm{t}$ & $\mathrm{p}$ & Cohen's d \\
\hline Married & 212 & 57.28 & 9.984 & \multirow{2}{*}{2.38} & \multirow{2}{*}{.016} & \multirow{2}{*}{0.73} \\
Unmarried & 188 & 49.98 & 10.104 & & & \\
\hline
\end{tabular}

$d f=398$

Table 11 shows significant differences of soldier's salary on JSS because it describes that the highly paid soldiers have a higher scores $(\mathrm{M}=43.20, \mathrm{SD}=4.65)$ than low paid soldiers $(\mathrm{M}=39.84, \mathrm{SD}=8.51), \mathrm{t}(398)=2.99, \mathrm{p}=.003, d=0.49$. The results of Table 12 also illustrate significant differences of soldiers' pay level on SWLS. It shows that high paid soldiers have a higher scores $(\mathrm{M}=55.63, \mathrm{SD}=9.36)$ than low paid soldiers $(\mathrm{M}=49.32, \mathrm{SD}=8.32), \mathrm{t}(398)=3.99, \mathrm{p}=.001, d=0.71$. These results indicate that high paid soldiers are more satisfied with their life and jobs than low paid soldiers. 
Table 11: Independent T-Test Analysis of High and Low Paid Employees on JSS

\begin{tabular}{llllllc} 
& \multicolumn{7}{c}{$(\mathrm{N}=400)$} & & \\
\hline High Paid & $\mathrm{N}$ & $\mathrm{M}$ & $\mathrm{SD}$ & $\mathrm{t}$ & $\mathrm{p}$ & Cohen's d \\
Low Paid & 170 & 43.20 & 4.654 & \multirow{2}{*}{2.99} & \multirow{2}{*}{.003} & \multirow{2}{*}{0.49} \\
\hline$d f=398$ & 230 & 39.84 & 8.514 & & & \\
\hline
\end{tabular}

Table 12: Independent T-Test Analysis of High and Low Paid Employees on SWLS

\begin{tabular}{|c|c|c|c|c|c|c|}
\hline & $\mathrm{N}$ & M & SD & $\mathrm{t}$ & $\mathrm{p}$ & Cohen's d \\
\hline High Paid & 170 & 55.63 & 9.364 & & & \\
\hline Low Paid & 230 & 49.32 & 8.324 & 3.987 & .001 & 0.71 \\
\hline
\end{tabular}

$d f=398$

\section{RESULTS and DISCUSSION}

The present research aimed at exploring the relationships between life satisfaction and job satisfaction among Pakistani army soldiers as well as exploring the age, education, pay, and marital status differences in job satisfaction and life satisfaction of Pakistani army soldiers. The first step was to find out the values of alpha coefficients for all instruments which were satisfactory; as JSS has .833 and SWLS has .789 (see Table 1) alpha coefficients. All the instruments also have good construct validities, as indicated by the significant high correlation between the items of the scales and their corresponding totals of JSS and SWLS (see Table $2 \& 3$ ).

The data analysis on the first hypothesis, regarding the relationship between job satisfaction and satisfaction with life revealed that there is a significant positive relationship between job satisfaction and satisfaction with life among Pakistani army soldiers (see Table 4). These results are in line with the findings of some previous researches (Andrews \& Withey, 1974a, 1976; Campbell, Converse, \& Rodgers, 1976; Hulin, 1969; London, Crandall, \& Seals, 1977; Rice, Near, \& Hunt, 1979), which revealed that job satisfaction and life satisfaction have a strong positive relationship with each other. However, some research has found that job satisfaction is not significantly related to life satisfaction when other variables such as non-work satisfaction and core self-evaluations are taken into account (Rode, 2004). In addition, Beehr (1995) proposed that there exists a positive relationship between work and life attitude. When people are satisfied with their jobs, they are also satisfied with their nonwork-related lives and attain happiness. Therefore, this study infers from the results that those people who are satisfied with their life will also be satisfied with their jobs and vice versa situation can also occur.

In the present study the differences of four demographic (age, education, marital status, and pay) are explored on job satisfaction and life satisfaction. Our data support the second hypothesis of the present study that older Pakistani army soldiers are more satisfied with their life and job as compared to the young Pakistani soldiers (see Table 5 \& 6). These results are consistent with previous research results (Diener \& Eunkook Suh as cited in Sousa \& Lyubomirsky, 2001) which found that reported life satisfaction and job satisfaction generally remained stable throughout the life span, showing just a slight increasing trend after the age of 20 years. 
The findings supported the third hypothesis of the current study that low educated Pakistani army soldiers are more satisfied with their jobs and life as compared to the highly educated Pakistani army soldiers (see Table $7 \& 8$ ). The results of some previous studies also support the findings of the current study (Argyle, 1999; Veenhoven, 1996), which demonstrate the negative relationship between education level of the respondents and their level of job satisfaction and life satisfaction. Poorer persons obtain greater satisfaction from education because the achievement surpasses their expectations of what is attainable. Education may also provide access to greater occupational and income opportunities, which may additionally influence life satisfaction and job satisfaction (Argyle, 1999).

At Pakistan unemployment level is very high and most of the young people join jobs which are not in accordance with their educational level. So, when these individuals compare their jobs with their salary level and current job status, they become depressed or tense. This might be one of the major reasons behind this result that low educated soldiers are more satisfied with their jobs and life than high educated soldiers.

Our finding for the fourth hypothesis portrayed significant positive association of employees' job satisfaction and life satisfaction with their marital status which in return support our hypothesis that married Pakistani soldiers are more satisfied with their jobs and lives as compared to single or unmarried Pakistani army soldiers (see Table 9 \& 10). These results are in line with the results of previous work (Bowen, Radhakrishna, \& Keyser, 1994; Cabrita \& Perista, 2006; Dodd-McCue \& Wright, 1996; Du, Song, Liu, \& Picken, 2007; Mosadeghrad, Ferlie \& Rosenberg, 2008; Salami, 2008) that married people are more satisfied with their jobs and lives as compared to unmarried people. Married persons demonstrated more emotional attachment than single employees. These results again indicated the tendency for married employees to be more family oriented and see the job as a kind of family provider while single employees are more selforiented, may view the employing organization only as a source of income and therefore feel less satisfied and less emotionally attached with their organizations.

The analyses of current study showed that highly paid Pakistani army soldiers are more satisfied with their jobs and lives as compared to the Pakistani army soldiers with low pay, which in return support the fifth hypothesis of the current study (see Table 11 $\&$ 12). The results of some previous studies (Headey \& Wearing, 1989; Pinquart \& Sorensen, 2000; Stevenson \& Wolfers 2008) also supported the current results by demonstrating a positive relationship between income of the person and his/her level of job satisfaction and life satisfaction. A robust finding in this literature concerns the distribution of wealth within a nation that is, the greater the economic disparities between income levels and classes in a nation, the greater the dissatisfaction with respect to job and life is expressed overall and the greater the disparity between satisfaction levels of the wealthy and the poor. Thus, the soldiers who live in poorer, less egalitarian nations tend to be less satisfied with their lives and jobs overall than the soldiers who live in wealthier nations (Headey \& Wearing, 1989).

In conclusion, it can be said that job satisfaction and life satisfaction of the Pakistani army soldiers are significantly positively related with each other. The results revealed that older Pakistani army soldiers were more satisfied with their lives and jobs than young soldiers. The findings of the current study demonstrated that low qualified 
Pakistani army soldiers have more job and life satisfaction than highly qualified soldiers. It was also found that married Pakistani army soldiers are more satisfied with their jobs and lives than single soldiers. With respect to salary of the Pakistani army soldiers, the results of data analyses revealed salary of the Pakistani army soldiers, has direct relation to their level of job and life satisfaction.

\section{Limitations and Suggestions}

The present study was conducted only on the Pakistani army soldiers of Taxila Cantt and Rawalpindi. Future research should be conducted with Pakistani army soldiers of different areas and also take samples from the Navy and Air Force. The present study only studied age, salary, marital status, and education differences on job and life satisfaction level while neglecting other demographic variables. For future research it is suggested that in order to get in-depth understanding of the relationship between job satisfaction and life satisfaction, the researcher should study some other important demographic variables (e.g., type of the unit, status of the soldier within the army, ethnicity, social class, youth cultures, and socioeconomic status) and their impact on life satisfaction and job satisfaction of Pakistani army soldiers.

\section{REFERENCES}

Ahlstrom, G., \& Sjoden, P. O. (1996). Coping with illness-related problems and quality of life in adult individuals with muscular dystrophy. Journal of Psychosomatic Research, 41(4), 365-376.

AL-Hussami, M. (2008). A Study of nurses' job satisfaction: The relationship to organizational commitment, perceived organizational support, transactional leadership, transformational leadership, and level of education. European Journal of Scientific Research, 22 (2), 286-295

Andrews, F. M., \& Withey, S. B. (1974a). Developing measures of perceived life quality: Results from several national surveys'. Social Indicators Research, 1, 1-26.

Andrews, F. M., \& Withey, S. B. (1976). Social indicators of well-being: America's perception of life quality. New York; Plenum Press.

Argyle, M. (1999). Causes and correlates of happiness. In D. Kahneman, E. Diener, \& N. Schwartz (Eds.), WELL-BEING: The Foundations of Hedonic Psychology (pp. 353-373). New York, US: Russell Sage.

Baloch, Q. B. (2008). Effects of job satisfaction on employee's motivation \& turn over intentions: From review of the related literature. Journal of Managerial Sciences, 2 (1), 1-21.

Barrett, A.J., \& Murk, P.J. (2006). Life satisfaction index for the third age (LSITA): A measurement of successful aging. In E. P. Isaac (Ed.), Proceedings of the 2006 Midwest Research-to-Practice Conference in Adult, Continuing, and Community Education (pp. 7-12). St. Louis: University of Missouri-St. Louis

Beehr, T. A. (1995). Psychological stress in the workplace. London: Routledge.

Boschen, K. A. (1996). Correlates of life satisfaction, residential satisfaction, and locus of control among adults with spinal cord injuries. Rehabilitation Counseling Bulletin, 39, 230-243 
Bowen, C. F., Radhakrishna, R., \& Keyser, R. (1994). Job satisfaction and commitment of 4-H Agents. Journal of Extension, 32 (1), 1-22.

Cabrita, J., \& Perista, H., (2006). Measuring job satisfaction in surveys -comparative analytical report. European Foundation for the Improvement of Living and Working Conditions. Retrieved from http://www.eurofound.europa.eu/ewco/reports/TN0608TR01/TN0608TR01.htm.

Camp, S. D. (1994). Assessing the effects of organizational commitment and job satisfaction on turnover: An event history approach. The Prison Journal, 74 (3), 279-305. DOI: 10.1177/0032855594074003002

Campbell, A., Converse, P. E., \& Rodgers, W. (1976). The quality of American life: perceptions, evaluations and satisfactions. New York: Russell Sage Foundation.

Chen, R. K., \& Crewe, N. M. (2009). Life satisfaction among people with progressive disabilities. Journal of Rehabilitation, 75 (2), 50-58

Decker, S. D., \& Schulz, R. (1985). Correlates of life satisfaction and depression in middle- aged and elderly spinal cord-injured persons. American Journal of Occupational Therapy, 39, 740-745.

Diener, E. (1990). Issues in defining and measuring subjective well-being. Manuscript submitted for publication.

Diener, E., \& Larsen, R. J. (1993). The subjective experience of emotional well-being. In M. Lewis \& J. M. Haviland (Eds.), Handbook of Emotions, (pp. 405-415). New York: Guilford Press.

Diener, E., \& Emmons, R. A. (1985). The independence of positive and negative affect. Journal of Personality and Social Psychology, 47, 1105-1117.

Diener, E., Emmons, R. A., Larsen, R. J., \& Griffin, S. (1985). The satisfaction with life scale. Journal of Personality Assessment, 49, 71-75

Diener, E., Suh, E. M., Lucas, R. E., \& Smith, H. L. (1999). Subjective well-being: Three decades of progress. Psychological Bulletin, 125, $276-302$.

Dodd-McCue, D. \& Wright, G. B. (1996). Men, women and attitudinal commitment: The effects of workplace experiences and socialization. Human Relations, 49 (8), 1065-1089.

Du, J., Song, Y., Liu, C., \& Picken, D. (2007). Variance analyses of job satisfaction and organizational commitment vs. demographic variables: A study on construction managers in Wuhan. Management Challenges in a Global World: Proceedings of the Sixth Wuhan International Conference on E-Business (pp. 1332-1337).New York: Alfred University Press.

Emmert, A. M., \& Taher, W. A. (1992). Public sector professionals: The effect of public sector jobs on motivation, job satisfaction and work involvement. American Review of Public Administration, 22 (1), 37-48.

Ewen, R., Smith, P., Hulin, C., \& Locke, E. (1966). An empirical test of the Hertzberg two factor theory. Journal of Applied Psychology, 50 (6), 544-550.

Gawel, J. E. (1997). Herzberg's theory of motivation and Maslow's hierarchy of needs. Practical Assessment, Research \& Evaluation, 5 (11). Retrieved from http://PAREonline.net/getvn.asp? $\mathrm{v}=5 \& \mathrm{n}=11$ 
Gruenberg, B. (1980). The happy work: An analysis of educational and occupational differences in determinants of job satisfaction. The American Journal of Sociology, 86 (2), 247-271.

Hackman, J., \& Lawler, E. E. III. (1971). Employee reactions to job characteristics. Journal of Applied Psychology, 55, 259-286.

Haleem, W. (2001). To study the relationship between job satisfaction and organizational commitment in bankers. Unpublished M.Phil. dissertation, National Institute of Psychology, Quaid-i-Azam University, Islamabad, Pakistan

Harrick, E. J., Vanek, G. R., \& Michlitsc, J. F. (1986). Alternative work schedules, productivity, leave usages and employee attitude: A field study. Public Personnel Management, 15, 159-169.

Headey, B., \& Wearing, A. (1989). Personality, life events, and subjective well-being: Toward a dynamic equilibrium model. Journal of Personality and Social Psychology, 57, 731-739.

Herzberg, F. (1966). Work and the nature of man. Cleveland, OH: The World Publishing Company.

Hulin, C. L. (1969). Sources of variation in job and life satisfaction: The role of community and job related variables. Journal of Applied Psychology, 53 (4), 279291.

Hussain, S. (2006). Perceived procedural justice and its impact on organizational commitment and job satisfaction. Unpublished M.Phil. dissertation, National Institute of Psychology, Quaid-i-Azam University, Islamabad, Pakistan.

Judge, T. A., \& Watanabe, S. (1994). Individual differences in the nature of the relationship between job and life satisfaction. Journal of Occupational and Organizational Psychology, 67, 101-107

Kalleberg, A. (1977). Work values and job rewards: A theory of job satisfaction. American Sociological Review, 42, 124-143.

Krause, J. S., \& Dawis, R. (1992). Prediction of life satisfaction after spinal cord injury: A four-year longitudinal approach. Rehabilitation Psychology, 37, 49-59.

Lahiri, D., \& Srivastua, S. (1967). Determinants of satisfaction in middle management personnel. Journal of Applied Psychology, 51 (3), 254-265.

Lambert, E. G. (2004). The impact of job characteristics on correctional staff members. The Prison Journal, 84 (2), 208-227.

Levin, I., \& Stokes, J. P. (1989). Dispositional approach to job satisfaction: Role of negative affectivity. Journal of Applied Psychology, 74, 752-758.

Locke, E. A. (1976). The nature and causes of job satisfaction. In M. D. Dunnette (Ed.), Handbook of Industrial and Organizational Psychology (pp.1297-1343). Chicago: Rand McNally.

London, M., Crandall, R., \& Seals, G. W. (1977). The contribution of job and leisure satisfaction to quality of life. Journal of Applied Psychology, 63 (3), 328-334.

Lounsbury, J. W., Moffitt, L., Gibson, L. W., Drost, A. W., \& Stevenson, M. W. (2007). An investigation of personality traits in relation to the job and career satisfaction of information technology professionals. Journal of Information Technology, 22, 174-183. 
Martin, J., \& Hanson, S. (1985). Sex, family wage earning status, and satisfaction with work. Work and Occupations, 12, 91-105.

Manisera, M., Dusseldorp, E., \& Kooij, A. J. (2005). Component structure of job satisfaction based on Herzberg's theory. Unpublished manuscript, Department of Quantitative Methods, University of Brescia, Brescia, Italy.

McCabe, M. P., \& De Judicibus, M. (2005). The effects of economic disadvantage on psychological well-being and quality of life among people with multiple sclerosis. Journal of Health Psychology, 10(1), 163-173.

Macdonald, S., \& Maclntyre, P. (1997). The generic job satisfaction scale: Scale development and its correlates. Employee Assistance Quarterly, l3 (2), 1-16.

Mehnert, T., Krauss, H. H., Nadler, R., \& Boyd, M. (1990). Correlates of life satisfaction in those with disabling conditions. Rehabilitation Psychology, 35(1), 317.

Mosadeghrad, A. M., Ferlie, E., \& Rosenberg, D. (2008). A study of the relationship between job satisfaction, organizational commitment and turnover intention among hospital employees. Health Services Management Research, 21(4), 211-227.

Near, J. P. (1983). Relationship between job satisfaction and life satisfaction: Test of a causal modal. Social Indicators Research, 15, 351-367.

Near, J. P., Rice, R. W., \& Hunt, R. G. (1978). Work and extra-work correlates of life and job satisfaction. Academy of Management Journal, 21, 248-264.

Nozick, R. (1974). Anarchy, state, and utopia. New York: Basic Books

Pavot, W. \& \& Diener, E. (1993). Review of satisfaction with life scale. Psychological Assessment, 5 (2), 164-172

Perera, K. (2007). Life satisfaction and self-esteem. Retrieved from www.moreselfesteem.com/self_esteem.htm

Pinquart, M., \& Sorensen, S., (2000). Influences of socioeconomic status, social network, and competence on subjective well-being in later life: A meta-analysis. Psychology and Aging, 15, 187-224

Rain, J. S., Lane, I.M. \& Steiner, D. D. (1991). A current look at the job satisfaction/life satisfaction relationship: Review and future considerations. Human Relations, 44, 287-307.

Rice, R. W., Near, J. P., \& Hunt, R. G. (1980). The job-satisfaction/life-satisfaction relationship: A review of empirical research. Basic and Applied Social Psychology, 1, 37-64.

Rode, J. C. (2004). Job satisfaction and life satisfaction revisited: A longitudinal test of an integrated model. Human Relations, 57 (9), 1205-1231

Shin, D. C., \& Johnson, D. M. (1978). Avowed happiness as an overall assessment of the quality of life. Social Indicators Research, 5, 475-492

Salami, S. O. (2008). Demographic and psychological factors predicting organizational commitment among industrial workers. Anthropologist, 10 (1), 31-38.

Sousa, L., \& Lyubomirsky, S. (2001). Life satisfaction. In J. Worell (Ed.), Encyclopedia of women and gender: Sex similarities and differences and the impact of society on gender (Vol, 2, pp. 667-676). San Diego, CA: Academic Press. 
Stevenson, B. \& Wolfers, J. (2008). Economic growth and subjective well-being: Reassessing the easterlin paradox. Brookings Papers on Economic Activity, 1, 1-87.

Sumner, L. W. (1996). Welfare, happiness, and ethics. New York: Oxford Press.

Tait, M., Padgett, M. Y., \& Baldwin, T. T. (1989). Job and life satisfaction: A reevaluation of the strength of the relationship and gender effects as a function of the date of the study. Journal of Applied Psychology, 74 (3), 502-507.

Taylor, G. S., \& Vest, M. J. (1992). Pay comparisons and pay satisfaction among public sector employee. Public Personnel Management, 21, 445-454.

Tewksbury, R., \& Higgins, G. E. (2006). Examining the effect of emotional dissonance on work stress and satisfaction with supervisors among correctional staff. Criminal Justice Policy Review, 17 (3), 290-301.

Voydanoff, P. (1980). Perceived job characteristics and job satisfaction among men and women. Psychology of Women Quarterly, 5 (2), 177-185.

Veenhoven, R. (1996). Developments in satisfaction research. Social Indicators Research, 37, 1-46

Viemero, V., \& Krause, C. (1998). Quality of life in individuals with physical disabilities. Psychotherapy and Psychosomatics, 67(6), 317-322.

Vroom, V. (1964). Work motivation. New York: John Wily and Sons.

Weiss, H. M. (2002). Deconstructing job satisfaction-Separating evaluations, beliefs and affective experiences. Human Resource Management Review, 12 (2), 173-194

Weiner, Y. (1982). Commitment in organizations: A normative view. Academy of Management Review, 7, 418-428.

$\mathrm{Wu}$, L., \& Norman, I., (2006). An investigation of job satisfaction, organizational commitment and role conflict and ambiguity in a sample of Chinese undergraduate nursing students. Nurse Education Today, 26 (4), 304-314. 